\title{
Licensed merchandise buying behavior of sports fans (Gaziantep Sport Store sample)
}

\author{
Huseyin OZTURK
}

School of Physical Education and Sport, Gaziantep University, Gaziantep, Turkey.

Address Correspondence to H. Ozturk, e-mail; ozturkavrasya@hotmail.com

\begin{abstract}
This study has been prepared to determine licensed team merchandise buying behavior of the fans that are coming to Gaziantep Sport Store to buy licensed merchandises. Research sample comprise of 439 people who are coming to Gaziantep Sport Store between the years of 2013-2015. Frequency, percentage, average, standard deviation have been used in evaluation; student t-test has been used for two independent groups having variables with normal distribution; ANOVA and LSD multiple comparison tests have been used for comparing more than two independent groups having variables with normal distribution. As a result of the study, the fans who are buying licensed merchandises in Gaziantep Sport Store, mostly watching the matches in the stadium; they prefer buying more licensed merchandises to identify with the team and support them; men prefer buying more licensed merchandise than women because of their loyalty and team identification while women prefer buying licensed merchandises more than men because of shopping enjoyment. When the style of watching Gaziantep Sport matches has been examined, it has been determined that there is a significantly difference between underlying dimensions of team identification, support, atmosphere, loyalty and shopping enjoyment.
\end{abstract}

Keywords: Fan, licensed product, sport.

\section{INTRODUCTION}

Sport has an important role in community life. Olympiads and sports organizations have been coordinated since ancient ages and with the development of technology they can be spectated all over the world and also participation in these organizations has increased (39). Other developments like satellite receivers, internet, and digital publishing and information technologies have provided the sports industry to become globalized (12).

Sport is a great power throwing people together at once. As a result of this power, sports fans have been identifying with their teams. This identification has been raised their self-confidence and socializing level. The fans whose identification is higher are pleased with the success of their team and feel sad when their team is defeated (17). Another important indicator to identification with the team is buying a range of goods of the team which are representing the color or other specifying points of the sports team (13). In other words fans have been stating their loyalty with using licensed merchandises belong to their teams $(25,38)$. This feature have been had an important impact on social life and have gained popularity. One of the underlying reasons of the sports' turning into a big industry is its social force (5).

Development of sports industry has been increased the number of sports enterprises and merchandises. Each store and sports team merchandise means competition. The competition term has the meaning for a sport company come into a range of operations with other companies to gain consumers (7). Football has the biggest share in sports industry without question. The conducted researches have been revealed that the football industry has created almost 250-300 billion dollar endorsement and value-added annually (1). It has been thought that nearly 1.4 billion people give importance to football and follow football activities. The spectators who watch the world cup final live on TV are nearly 33 million people (14).

It is impossible to change wideness of the football fans within other sport branches (4). The fans have the intention of buying the merchandises which are belong to their sports team (34). One of the important determinants of purchasing is quality perception $(10,36)$. Being a licensed merchandise or not is seen as a quality conformity level to buy a 
product, that's why they prefer to buy licensed merchandises $(14,20,31)$.

The football with its thousands registered players is the most popular sport in the world. Sports merchandises which have been selling since ancient Olympiads (4) have gained a place in the market which has been increasingly globalized, growing and increasing its economic importance each passing day. Licensed team merchandise buying behavior is one of the most important sources of income of sports team in the commercialization success in sports $(21,22)$.

This study has been prepared to investigate the factors influencing the merchandise buying behavior of the sports fans in Gaziantepspor Store. According to results of the analysis, these factors are team identification and support, atmosphere of the store, friend group, loyalty and shopping enjoyment.

\section{MATERIAL AND METHOD}

\section{Research Method}

This study has been figured according to descriptive research method. Descriptive researches are aimed at determination of a condition about any matter (24). Descriptive researches try to find out the conditions, features and the relation between them instead of putting emphasis on the reasons $(9,23)$.

\section{Population and Sample}

The sample in this study consists of people who buying team merchandises in Gaziantepspor Store between the years of 2013-2015. The demographic features of the participants have been given in Table 1. The random sampling has been used while the population selection has been done. Every person in the population has equal chosen chance in random sampling method (3). 500 pieces data collection tool conducted to Gaziantepspor Store customers who have been included in the study. 61 of the data collection tools have been eliminated by reasons of coding of missing data or coding the same point to all items. A total of 439 people have been included to sample by random sampling method.

The distribution of the responds about characteristics of the sample has been given in Table 1. It has been seen that $31.4 \%$ (138 people) of the participants are female, $68.4 \%$ (301 people) of them are male. $54.4 \%$ (239 people) of the participants are married, 39\% (171 people) of the participants mostly in the $19-24$ age group, $36.4 \%$ (160 person) of them are students, $52.6 \%$ (231 person) of them have an income of $2001 \mathrm{TL}$ and more, $50.3 \%$ (221 person) of them have high school education, 52.6\% (231 person) of them have been spending maximum 101$251 \mathrm{TL}$ at Gaziantepspor Store annually and 59.2\% (260 person) of them watching the football matches at the stadium.

\section{Data Collection Method}

The scanning method has been used as research method in order to be descriptive, correlative, objective and appropriate to statistical analysis. The scale has been developed by Kwon \& Armstrong (26) related to the factors influencing the licensed sports team merchandise buying behavior has been used in this study, Turkish cultural adaptation of this scale has been made by Argan (2) and the validity and reliability studies have been made on the fans or customers of Fenerium Store $(2,26)$.

\section{Data Analysis}

The factors influencing the licensed sports team merchandise purchase prepared by five-point Likert Scale. The Cronbach Alpha internal consistency coefficient which has been estimated for reliability of the scale reported as 0.89 . SPSS for Windows 22 has been used in the analysis of data. Frequency, percentage, averaging and standard deviation values have been given as descriptive statistics. Ttest has been implemented for two independent groups having variables with normal distribution, ANOVA and LSD multiple comparison tests have been implemented for comparing more than two independent groups having variables with normal distribution for the study. $\mathrm{P}<0.05$ considered as significant in statistical analysis.

\section{RESULTS}

When it has been considered the licensed team merchandise buying behavior, the highest average is underlying dimensions of team identification/ support while the lowest average is underlying dimensions of friend group in Table 2.

When Table 3 has been examined related to licensed sports team merchandise buying behavior in underlying dimensions of team identification/ support, loyalty and shopping enjoyment there has been a significant difference between woman and man according to gender.

In this comparison averages in underlying dimensions of team identification/support and loyalty to the team is significantly higher among male fans compared to the female fans while averages in underlying dimensions of enjoyment in shopping is significantly higher among female fans. 
The averages of underlying dimension of team identification/support and loyalty of the fans watching the matches in the stadium is significantly higher than the fans watching the matches live from the broadcasting organization and the fans following the matches from the summaries in the television channels.

Table 1. The demographic features of the participants.

\begin{tabular}{|c|c|c|c|}
\hline Variables & Groups & $\mathrm{N}$ & $\%$ \\
\hline \multirow[t]{2}{*}{ Gender } & Woman & 138 & 31.4 \\
\hline & Man & 301 & 68.6 \\
\hline \multirow[t]{2}{*}{ Civil Status } & Married & 239 & 54.4 \\
\hline & Bachelor & 200 & 45.6 \\
\hline \multirow[t]{4}{*}{ Age } & 18 aged and below & 100 & 22.8 \\
\hline & 19-24 aged & 171 & 39 \\
\hline & 25-30 aged & 98 & 22.3 \\
\hline & 31 aged and older & 70 & 15.9 \\
\hline \multirow[t]{5}{*}{ Occupation } & Worker/Civil Servant & 60 & 13.7 \\
\hline & Student & 160 & 36.4 \\
\hline & Director/Employer & 100 & 22.8 \\
\hline & Athlete & 119 & 27.1 \\
\hline & $1000 \mathrm{TL}$ and less & 120 & 27.3 \\
\hline \multirow[t]{3}{*}{ Monthly Income } & $1001-2000 \mathrm{TL}$ & 88 & 20 \\
\hline & 2001 TL and more & 231 & 52.6 \\
\hline & Primary School & 58 & 13.2 \\
\hline \multirow[t]{3}{*}{ Education Status } & High School & 221 & 50.3 \\
\hline & Undergraduate and Postgraduate & 160 & 36.4 \\
\hline & 100 TL and less & 158 & 36 \\
\hline \multirow[t]{3}{*}{ Annual Average Shopping } & btw 101-250 TL & 231 & 52,6 \\
\hline & $251 \mathrm{TL}$ and more & 50 & 11.4 \\
\hline & In the stadium & 260 & 59.2 \\
\hline \multirow[t]{2}{*}{ The Way of Watching Football Competitions } & Live on TV & 79 & 18 \\
\hline & Watching summary in TV channels & 100 & 22.8 \\
\hline
\end{tabular}

Table 2. The averages of underlying dimensions of licensed team merchandise buying behavior scale of participants.

\begin{tabular}{lccccc}
\hline Variables & $\mathrm{n}$ & Mean & SD & $\mathrm{z}$ & $\mathrm{p}$ \\
\hline Team identification/Support & 439 & 4.34 & 0.50 & 2.14 & 0.00 \\
Atmosphere & 439 & 4.16 & 0.74 & 2.85 & 0.00 \\
Friend Group & 439 & 1.96 & 1.03 & 2.05 & 0.00 \\
Loyalty & 439 & 3.69 & 1.05 & 3.23 & 0.00 \\
Shopping enjoyment & 439 & 3.97 & 0.98 & 4.23 & 0.00
\end{tabular}

Table 3. Comparison of sport team licensed merchandise buying scale points according to gender.

\begin{tabular}{lllllll}
\hline \multirow{2}{*}{ Team identification/Support } & & $\mathrm{n}$ & Mean & $\mathrm{SD}$ & $\mathrm{t}$ & $\mathrm{p}$ \\
& Woman & 138 & 4.24 & 0.45 & 2.84 & $0.00^{*}$ \\
\multirow{2}{*}{ Atmosphere } & Man & 301 & 4.39 & 0.51 & & \\
\multirow{3}{*}{ Friend Group } & Woman & 138 & 4.05 & 0.37 & 2.11 & 0.35 \\
\multirow{3}{*}{ Loyalty } & Man & 301 & 4.21 & 0.86 & & \\
\multirow{3}{*}{ Shopping Enjoyment } & Woman & 138 & 1.96 & 0.86 & 0.77 & 0.93 \\
& Man & 301 & 1.95 & 1.11 & & \\
& Woman & 138 & 3.31 & 0.90 & 5.25 & $0.00^{*}$ \\
& Man & 301 & 3.86 & 1.07 & \multirow{2}{*}{0.74} & $0.00^{*}$
\end{tabular}


Table 4. Comparison of sport team licensed merchandise buying scale points according to manner of following matches.

\begin{tabular}{|c|c|c|c|c|c|c|c|}
\hline & Manner of Following Football Matches & $\mathrm{n}$ & Mean & SD & $\mathrm{F}$ & $\mathrm{P}$ & Significant Difference \\
\hline Team identification & (a) In the stadium & 260 & 4.49 & 0.48 & & & \\
\hline \multirow[t]{2}{*}{ /Support } & (b) Live on TV & 79 & 4.04 & 0.22 & 34.18 & $0.00^{*}$ & $a-b, a-c, c-b$ \\
\hline & (c) Watching summary in TV channels & 100 & 4.20 & 0.55 & & & \\
\hline \multirow[t]{3}{*}{ Atmosphere } & (a) In the stadium & 260 & 4.24 & 0.92 & & & \\
\hline & (b) Live on TV & 79 & 3.96 & 0.19 & 4.28 & $0.01^{*}$ & $a-b$ \\
\hline & (c) Watching summary in TV channels & 100 & 4.12 & 0.39 & & & \\
\hline \multirow[t]{3}{*}{ Friend Group } & (a) $1000 \mathrm{TL}$ and less & 260 & 2.03 & 1.15 & & & \\
\hline & (b) btw $1001-1500$ & 79 & 1.86 & 0.80 & 1.82 & 0.16 & \\
\hline & (c) btw 1501-2000 & 100 & 1.83 & 0.86 & & & \\
\hline \multirow[t]{3}{*}{ Loyalty } & (a) In the stadium & 260 & 3.88 & 1.14 & & & \\
\hline & (b) Live on TV & 79 & 3.17 & 1.00 & 14.90 & $0.00^{*}$ & $a-b, a-c, c-b$ \\
\hline & (c) Watching summary in TV channels & 100 & 3.60 & 0.62 & & & \\
\hline \multirow[t]{3}{*}{ Shopping enjoyment } & (a) In the stadium & 260 & 3.82 & 1.04 & & & \\
\hline & (b) Live on TV & 79 & 3.98 & 1.00 & 10.67 & $0.00^{*}$ & $a-c, b-c$ \\
\hline & (c) Watching summary in TV channels & 100 & 4.35 & 0.63 & & & \\
\hline
\end{tabular}

Table 5. Comparison of sport team licensed merchandise buying scale points according to monthly income.

\begin{tabular}{|c|c|c|c|c|c|c|c|}
\hline & & $\mathrm{n}$ & Mean & $\mathrm{SD}$ & $\mathrm{F}$ & $\mathrm{p}$ & Significant Difference \\
\hline Team Identifications/ & (a) $1000 \mathrm{TL}$ and less & 120 & 4.38 & 0.58 & & & \\
\hline \multirow[t]{2}{*}{ Support } & (b )btw 1001-1500 & 88 & 4.37 & 0.45 & 1.01 & 0.36 & \\
\hline & (c) btw 1501-2000 & 231 & 4.31 & 0.47 & & & \\
\hline \multirow[t]{3}{*}{ Atmosphere } & (a) $1000 \mathrm{TL}$ and less & 120 & 4.22 & 1.07 & & & \\
\hline & (b) btw 1001-1500 & 88 & 4.39 & 0.57 & 8.05 & $0.00^{*}$ & $a-b, a-c$ \\
\hline & (c) btw 1501-2000 & 231 & 4.02 & 0.54 & & & \\
\hline \multirow[t]{3}{*}{ Friend Group } & (a) $1000 \mathrm{TL}$ and less & 120 & 2.30 & 1.21 & & & \\
\hline & (b) btw $1001-1500$ & 88 & 2.17 & 1.17 & 16.87 & $0.00^{*}$ & $a-b, a-c$ \\
\hline & (c) btw 1501-2000 & 231 & 1.96 & 0.78 & & & \\
\hline \multirow[t]{3}{*}{ Loyalty } & (a) $1000 \mathrm{TL}$ and less & 120 & 3.66 & 1.01 & & & \\
\hline & (b) btw $1001-1500$ & 88 & 3.92 & 1.04 & 37.18 & 0.27 & \\
\hline & (c) btw 1501-2000 & 231 & 4.00 & 0.93 & & & \\
\hline \multirow[t]{3}{*}{ Shopping enjoyment } & (a) $1000 \mathrm{TL}$ and less & 120 & 4.25 & 1.16 & & & \\
\hline & (b) btw 1001-1500 & 88 & 3.18 & 1.21 & 43.35 & $0.00^{*}$ & $a-b, a-c$ \\
\hline & (c) btw $1501-2000$ & 231 & 4.13 & 0.51 & & & \\
\hline
\end{tabular}

The averages of underlying dimension of team identification/support and loyalty of the fans following the matches from the summaries in the television channels is significantly higher than the fans watching the matches live from the broadcasting organization. The averages of underlying dimension of atmosphere of the fans watching the matches in the stadium is significantly higher than the fans watching the matches live from the broadcasting organization.

The averages of underlying dimension of shopping enjoyment of the fans following the matches from the summaries in the television channels is significantly higher than the fans watching the matches live from the broadcasting organization and the fans watching the matches in the stadium.

The averages of the underlying dimension of atmosphere and monthly income of the fans having income of $1000 \mathrm{TL}$ and less is less than the fans having income between 1001-1500 TL and higher than the fans having income between 1501-2000 TL.

The averages of the underlying dimension of monthly income, friend group and shopping enjoyment of the fans having income between 1001$1500 \mathrm{TL}$ is higher than the fans having income of $1000 \mathrm{TL}$ and less and the fans having income between 1501-2000 TL. 


\section{DISCUSSION}

It has been seen that most of the participants are high school graduates. There have been similar and different studies in the literature. Similarly, in the study which has been done by Turksoy et al. (37) and named as Social Identity and Perspective on Violence of the Fans of Tree Big Football Club, it has been seen that mostly high school graduates have participated in this study (37). The high school graduates are placed on the top in the study which has been done by Caglayan (11) and named as The Role of the Football Spectators' Social-EconomicalCultural Structure on Tendency to Violence (Konyaspor Sample). As a result of the study which has been done by Kurtic (27) and named as Psychosocial Factors Pushing Football Spectators to Aggression (Sakarya Province Sample), it has been seen that mostly high school graduates have participated in this study (27).

When it has been examined the occupations of the participants, mostly students have participated in this study. There have been different studies in the literature. As a result of the study which has been done by Eser (13) and named as "Licensed Merchandise Buying Behavior: A Study about Customers Purchasing from Eses Store", mostly employees have bought licensed merchandises. As a result of the study which has been done by Aytac (4) and named as Analysis of Buying Behaviors of the Fans Related to Licensed Merchandise Marketing Activities in Sports Clubs, most of the participants are civil servants.

It has been seen that most of the participants are watching the football matches in the stadium. There have been similar and different studies in the literature. Similarly, the study which has been done by and named as Corporate Marketing in Sports Clubs, it has been concluded that most of the spectators watching the matches in the stadium. Differently, as a result of the study which has been done by Eser (13), most of the fans purchasing from Es-es Store are mostly watching the matches live from the broadcasting organization.

When it has been considered the licensed team merchandise buying behavior, the highest average is underlying dimensions of team identification/ support while the lowest average is underlying dimensions of friend group.

Likewise, as a result of the study which has been done by Harolle et al. (18) and named as Loyalty of Baseball Spectators, it has been seen that team identification of the fans is high. It has been concluded that if ones licensed sports team merchandise buying intention is high, his or her team identification/support dimension is high too $(6,32,36)$. Besides team identification/support dimension, high level of emotional commitment has been seen very effective in licensed sport teamer chandise buying behavior $(18,19)$.

As a result of the other studies, it has been concluded that team identification and licensed sports team merchandise buying intention are interrelated with one another $(8,15,28)$. Lee et al. $(28)$ have indicated that there is a positive relation between team identification and brand loyalty. Nevertheless, Quick (33) has indicated that there is a relation between irrational emotions of team identification and consumption of sport merchandises. Josepet al. (21) have confirmed in their "Multivariate Data Analysis" study that there is a positive and significant relation between team identification and the manner related to sponsor brand (21).

There has been a significant difference between female and male participants in comparison with licensed sports team merchandise buying behavior and underlying dimensions of team identification/support, loyalty and shopping enjoyment according to gender. In this comparison averages in underlying dimensions of team identification/support and loyalty to the team is significantly higher among male fans compared to the female fans while averages in underlying dimensions of enjoyment in shopping is significantly higher among female fans.

The averages of underlying dimension of team identification/support and loyalty of the fans watching the matches in the stadium is significantly higher than the fans watching the matches live from the broadcasting organization and the fans following the matches from the summaries in the television channels. The averages of underlying dimension of team identification/support and loyalty of the fans following the matches from the summaries in the television channels is significantly higher than the fans watching the matches live from the broadcasting organization. The averages of underlying dimension of atmosphere of the fans watching the matches in the stadium is significantly higher than the fans watching the matches live from the broadcasting organization. The averages of underlying dimension of shopping enjoyment of the fans following the matches from the summaries in 
the television channels is significantly higher than the fans watching the matches live from the broadcasting organization and the fans watching the matches in the stadium.

The averages of the underlying dimension of atmosphere and monthly income of the fans having income of $1000 \mathrm{TL}$ and less is less than the fans having income between 1001-1500 TL and higher than the fans having income between 1501-2000 TL. The averages of the underlying dimension of monthly income, friend group and shopping enjoyment of the fans having income between 1001$1500 \mathrm{TL}$ is higher than the fans having income of $1000 \mathrm{TL}$ and less and the fans having income between 1501-2000 TL.

In conclusion; the licensed sport team merchandise buying behavior plays extremely important part in sport industry and it has been stated billions of dollars in today's world. Sport Clubs have been creating high income from the sales of licensed sports merchandises. Economic performance is one of the important factors in sportive success like every field basing on economy. If the team is economically powerful; it is easier to gain sportive success. This study has been prepared to determine licensed team merchandise buying behavior of the fans. Five main underlying dimensions (team identification/support, atmosphere, friend group, loyalty and shopping enjoyment) have been affecting the licensed team merchandise buying decisions of the fans. It has been seen that the highest average is underlying dimension of team identification/support and the least average is underlying dimension of friend group within these dimensions.

Most of the participants have been watching the matches in stadium, averages in underlying dimensions of team identification/support and loyalty to the team is significantly higher among male fans compared to the female fans while averages in underlying dimensions of enjoyment in shopping is significantly higher among female fans.

The averages of underlying dimension of team identification/support and loyalty of the fans watching the matches in the stadium is significantly higher than the fans watching the matches live from the broadcasting organization and the fans following the matches from the summaries in the television channels. The averages of underlying dimension of team identification/support and loyalty of the fans following the matches from the summaries in the television channels is significantly higher than the fans watching the matches live from the broadcasting organization. The averages of underlying dimension of atmosphere of the fans watching the matches in the stadium is significantly higher than the fans watching the matches live from the broadcasting organization. The averages of underlying dimension of shopping enjoyment of the fans following the matches from the summaries in the television channels is significantly higher than the fans watching the matches live from the broadcasting organization and the fans watching the matches in the stadium.

The averages of the underlying dimension of atmosphere and monthly income of the fans having income of $1000 \mathrm{TL}$ and less is less than the fans having income between 1001-1500 TL and higher than the fans having income between 1501-2000 TL. The averages of the underlying dimension of monthly income, friend group and shopping enjoyment of the fans having income between 1001$1500 \mathrm{TL}$ is higher than the fans having income of $1000 \mathrm{TL}$ and less and the fans having income between 1501-2000 TL.

\section{REFERENCES}

1. Aksar T. Endustriyel Futbol, İstanbul: Literatur Yayınlari, 2005.

2. Argan M. Licensed Merchandise Buying Behavior: A Research On Persons Shopping in Fenerium Store, 8. SBD Uluslararasi Spor Bilimleri Kongresi, 2004.

3. Arli, Nazik H. Bilimsel Arastirmaya Giris. Ankara: Gazi Kitabevi, 2004

4. Aytac KY. Taraftarlarin Spor Kuluplerindeki Lisansli Urun Pazarlama Faaliyetlerine İliskin Satin Alma Tutumlarinin Incelenmesi,Yuksek Lisans Tezi, Gazi Universitesi Saglik Bilimleri Enstitusu Beden Egitimi ve Spor Anabilim Dali, Ankara, 2009.

5. Barker K. Ad rules relaxed for NFL bash: Mall promotions amountto sponsor recognition, Park Services says. The Washington Post, 2003.

6. Boulding W, Karla A, Staelin R, Zeithaml VA. A dynamic process model of service quality: from expectations to behavioral intentions. Journal of Marketing Research, 1993; 30(1): 7-27.

7. Burnet J, Mennon A, Smart D. Sport marketing- a new ball game with new rules. Journal of Advertising, 1996; 33(5): 2123.

8. Carlson B, Donovan T, Cumiskey K. Consumer brand relationships in sport: brand personality and identification. International Journal of Retail and Distribution Management, 2009; 37(4): 370-383.

9. Creswell JW. Educational research: Planning, conducting and evaluating quantitative and qualitative research. Upper Saddle River, NJ: Pearson Prentice Hall, 2005. 
10. Crosby P. Quality is Free: The Art of Making Quality Certain, New York, McGraw Hill Custom Publishing, 1979.

11. Caglayan SH. Futbol Seyircisinin Sosyo-ekonomik- Kulturel Yapisinin Sidet Egilimindeki Rolu Konyaspor Ornegi). Selcuk Universitesi Saglik Bilileri Enstitusu Spor Yoneticiligi Anabilim Dali, Konya, 2003.

12. Daniel SM. What is the sports product and who buys it the marketing of professional sports leagues. European Journal of Marketing, 1999; 33(3): 402-419.

13. Eser O. Lisanslı Ürün Satın Alma Davranışı: Eses Store'dan alışveriş yapan tüketiciler üzerine bir araştırma. Yuksek Lisans Tezi, Osmangazi Universitesi Sosyal Bilimler Enstitusu, Eskisehir, 2014.

14. Garvin D. Quality on The Line, Harvard Business Review, 1983; 61: 65-73.

15. Gau LS, James JD, Kim JC. Effects of team identification on motives, behavior outcomes, and perceived service quality. Asian Journal of Management and Humanity Science, 2009: 4(3); 76-90.

16. Giulianotti R, Robertson R. The globalization of football: a study in the glocalization of the 'serious life. The British Journal of Sociology, 2004: 55(4): 545-568.

17. Gullu M, Guclu M. Ortaöğretim öğrencilerinin taraftar oldukları spor takımları ile özdeşleşmelerinin incelenmesi. 9. Uluslararası Spor Bilimleri Kongresi Bildiriler Kitabı, 2006 pp. 686-689.

18. Han H, Kim Y, Kim E. Cognitive, affective, conative, and action loyalty: testing the impact of inertia. International Journal of Hospitality Management, 2011; 30: 1008-1019.

19. Hong IB, Cho $\mathrm{H}$. The impact of consumer trust on attitudinal loyalty and purchase intentions in B2C e-marketplaces: intermediary trust vs. seller trust. International Journal of Information Management, 2011; 31: 469-479.

20. Jacoby JR, Olson JC. Perceived quality, Lexington, MA Lexington Books, 1985

21. Joseph FH, William C, Black BJ, Babin RE. Multivariate Data Analysis, 7th Ed., New Jersey, Prentice Hall, 2009: 164-165.

22. Kolah A. Maximizing Revenue from Licensing and Merchandising, Sport Business Group, London, 2005.

23. Kaptan S. Bilimsel Araştırma ve İstatistik Teknikleri. Ankara: Bilim Yayınları, 1995.

24. Karasar N. Sosyal Bilimlerde Araştırma Yöntemleri. Ankara: Seckin Yayınları, 1998.

25. Kwak DK, Kang J. Symbolic Purchase in Sport: the roles of self-image congruence and perceived quality. Management Decision, 2009; 47(1): 85-99.
26. Kwon $\mathrm{HH}$, Armstrong KL. Factors influencing impulse buying of sport team licensed merchandise. Sport Marketing Quarterly, 2002; 11(3): 151-163.

27. Kurtic N. Futbol Seyircisini Saldırganlığa iten psiko-sosyal nedenler (Sakarya İl örneği). Sakarya Universitesi Sosyal bilimler Enstitusu, Beden Egitimi ve Spor Ogretmenligi, Yuksek Lisans Tezi, Sakarya, 2006.

28. Lee D, Trail GT. Confirmatory analysis of the athletic team merchandise model. Measurement in Physical Education and Exercise Science, 2012; 16(2): 101-118.

29. Lee S, Shin H, Park J, Kwon O. A brand loyalty model utilitizing team identification and customer satisfaction in the licensed sports product industry. ICHPER-SD Journal of Research, 2010; 5(1): 60-67.

30. MHinckley S. Team apparel contracts: licensing can help maximize benefits. Athletic Administration, 2004: 39,57.

31. Mitra D, Golder PN. How does objective quality affect perceived qualityi short-term effects, long-term effects and asymmetries. Marketing Science, 2006; 25: 230-47.

32. Parasuraman A, Zeithaml V, Berry L. The behavioral consequences of service quality. Journal of Marketing, 1996; 60: 31-46.

33. Quick S. Contemporary sport consumers: Some implications of linking fan typology with key spectator variables. Sport Marketing Quarterly, 2000; 9(3): 149-156.

34. Spears N, Singh SN. Measuring attitude toward the brand and purchase intentions. Journal of Current Issues and Research in Advertising, 2004; 26(2): 53-66.

35. Trail GT, James JD. The motivation scale for sport consumption: assessments of the scales psychometric properties. Journal of Sport Behavior, 2001; 24(1): 108-127.

36. Tsiotsou R. The role of perceived product quality and overall satisfaction on purchase intentions. International Journal of Consumer Studies, 2006; 30: 207-217.

37. Turksoy A, Cicek M, Bayansaldur M. Uç büyük kulüp futbol taraftarının sosyal kimlikleri ve şiddete bakış açıları. Istanbul Universitesi Spor Bilimleri Dergisi, 2003; 11(3): 94-99.

38. Wann DL, Branscombe NR. Sports fans: measuring degree of identification with their team. International Journal of Sport Psychology, 1993: 24(1): 17

39. Yavas O. Sporun Ekonomi içerisindeki yeri ve spor pazarlama: üç büyük spor kulübünde uygulamalı bir araştırma. Yüksek Lisans Tezi, Trakya Universitesi Sosyal Bilimler Enstitusü, Edirne,2005. 